\title{
Implementasi LDA Pada Fitur HOG Untuk Klasifikasi ASL Menggunakan K-NN
}

\author{
Muhammad Ezar Al Rivan*1, Hafiz Irsyad ${ }^{2}$, Kevin $^{3}$, Arta Tri Narta ${ }^{4}$ \\ ${ }^{1,2,3,4}$ STMIK Global Informatika MDP; Jalan Rajawali No.14, 0711-376400 \\ ${ }^{1,2,3,4}$ Program Studi Teknik Informatika, STMIK Global Informatika MDP, Palembang \\ e-mail:*11meedzhar@mdp.ac.id, ${ }^{2}$ hafizirsyad@mdp.ac.id, ${ }^{3}$ cosmoas13@gmail.com, \\ ${ }^{4}$ narta1208@gmail.com
}

\begin{abstract}
Abstrak
Sign language merupakan suatu cara alternatif yang bisa digunakan untuk berkomunikasi dengan menggunakan isyarat, salah satu jenisnya yaitu American Sign Language (ASL). Dataset sign language yang digunakan yaitu dalam bentuk dataset citra yang diproses menggunakan ekstraksi fitur Histogram of Oriented Gradients (HOG) dan selanjutnya direduksi menggunakan Linear Discriminant Analsysis (LDA). Selanjutnya hasil reduksi digunakan untuk klasifikasi K-Nearest Neighbors (k-NN). Tiga jenis distance yang digunakan yaitu euclidean, manhattan dan chebyshev. Hasil terbaik diperoleh menggunakan manhattan distance dengan nilai $K=3$ dengan presisi sebesar 72,42\%.
\end{abstract}

Kata kunci-ASL, HOG, LDA, K-NN

\begin{abstract}
Sign Language is alternative way to communication using sign. One of sign language is American Sign Language (ASL). Image from Dataset processed using feature extraction HOG then reduce using Linear Discriminant Analysis (LDA). The reduced feature used to K-Nearest Neighbor classification. There are 3 distance used consist of euclidean, manhattan and chebyshev. The best accuracy obtain from manhattan distance using $k=3$ with $72,42 \%$ precision.
\end{abstract}

Keywords-ASL, HOG, LDA, K-NN

\section{PENDAHULUAN}

ign language digunakan oleh tunarungu sebagai cara untuk berkomunikasi satu sama lain

$\mathrm{S}$ [1] Sign language berguna dalam kehidupan sehari-hari karena penggunaan sistem ini bisa dijadikan sebagai sarana komunikasi untuk memahami maksud dari lawan bicara dengan mengenali pola alfabet yang dibentuk jari sebagai isyarat dalam menyusun kata. Terdapat berbagai jenis bahasa sign language yang digunakan, salah satu adalah American Sign Language (ASL). Namun demikian masyarakat umum yang mempunyai kemampuan untuk berkomunikasi menggunakan sign language masih terbatas [2].

Penelitian terkait dengan ASL telah banyak diterapkan dengan berbagai macam metode klasifikasi dan ekstraksi fitur [3] [4]. Berdasarkan penelitian [5] [6] menunjukkan bahwa hasil akurasi yang diperoleh dengan menggunakan klasifikasi $k$-Nearest Neighbor (k-NN) serta ekstraksi fitur Histogram of Oriented Gradient (HOG) ataupun Linear Discriminant Analysis (LDA), yaitu sebesar 98,33\% dan 96\%. Pada penelitian [7] citra ASL diekstraksi fiturnya menggunakan HOG lalu menggunakan k-NN sebagai klasifikasinya. Kemudian penelitian 
lainnya [8] mengenai ekstraksi HOG juga memberikan hasil yang baik, yaitu 73,3\% untuk akurasi setiap gambar dan $86,67 \%$ untuk setiap number. Pada penelitian ini LDA digunakan sebagai reduksi fitur dari HOG untuk mengurangi ukuran fitur serta k-NN sebagai metode klasifikasi

\section{LANDASAN TEORI}

\subsection{American Sign Language (ASL)}

ASL diciptakan oleh Thomas Hopkis Gallaudet dan Laurent Clerc. Pada tahun 1817 Gallaudet membangun sekolah berlokasi di Hartford, Connecticut dan Clerc sebagai guru bahasa isyarat pertama di Amerika. Pada awalnya ASL digunakan sebagai bahasa isyarat untuk berkomunikasi dengan sesama tunarungu di lingkungan sekolah [3]. Perkembangan ASL membuat bahasa isyarat ini menjadi landasan bahasa isyarat di beberapa negara [9]. Pada ASL pergerakan jari merupakan bagian yang tidak bisa dihindari dari gestur tangan [10]. Data dari alfabet ASL diperlukan untuk proses pengenalan huruf A sampai Y kecuali J dan Z. Huruf J dan $\mathrm{Z}$ tidak digunakan karena bersifat dinamis, yaitu dalam pengenalan huruf $\mathrm{J}$ dan $\mathrm{Z}$ membutuhkan pergerakan dari jari, sedangkan yang dikenali adalah berupa citra.

\subsection{Histogram of Oriented Gradients (HOG)}

Histogram of Oriented Gradient (HOG) adalah sebuah metode yang digunakan dalam image processing untuk bertujuan deteksi objek. Teknik ini menghitung nilai gradient dalam daerah tertentu pada suatu image [11]. Tiap image mempunyai karakteristik yang ditunjukkan oleh distribusi gradient. Karakteristik ini diperoleh dengan membagi image kedalam daerah kecil yang disebut cell. Tiap cell disusun sebuah histogram dari sebuah gradient. Kombinasi dari histogram ini dijadikan sebagai descriptor yang mewakili sebuah obyek. Proses HOG memiliki tahapan, yaitu.

1. Melakukan normalisasi gamma dan warna citra

Citra full color (RGB) diubah menjadi citra scale.

2. Menghitung nilai gradient pada setiap piksel citra

Setelah diubah ke citra grayscale, proses selanjutnya yaitu membagi gambar menjadi wilayah kecil yang terhubung(cell). Setiap sel menghitung histogram dari arah gradient atau orientasi tepi untuk piksel dalam sel.

Untuk mencari nilai gradient perlu mencari nilai sumbu $\mathrm{x}$ dan sumbu $\mathrm{y}$.

Persamaaan untuk mencari sumbu $\mathrm{x}$ dapat dilihat pada persamaan (1).

$$
I_{x}(r, c)=I(r, c+1)-I(r, c-1)(1)
$$

Persamaan untuk mencari sumbu y dapat dilihat pada persamaan (2).

$$
I_{y}(r, c)=I(r-1, c)-I(r+1, c)(2)
$$

Sehingga diperoleh nilai $x$ dan $y$ yang digunakan untuk menghitung gradient magnitude (besar gradient). Persamaaan untuk mencari sumbu magnitude dapat dilihat pada persamaan (3).

$$
\mu=\sqrt{I_{x}+I_{y}}(3)
$$

setelah mendapat nilai $\mu$, dilanjutkan dengan mencari nilai orientasi gradient, Persamaaan untuk mencari orientasi gradient dapat dilihat pada persamaan (4). 


$$
\theta=\frac{180}{\pi}\left(\tan _{2}^{-1}\left(I_{y}, I_{x}\right) \bmod \pi\right)(4)
$$

3. Akumulasi Bobot nilai untuk orientasi gradient di dalam ruang cell

Setelah mendapat nilai magnitude $(\mu)$ dan orientasi gradient $(\theta)$ tiap blok, tahapan proses pada selanjutnya yaitu mencari nilai orientasi cell histogram, Persamaaan untuk mencari nilai orientasi cell histogram, dapat dilihat pada persamaan (5).

$$
C_{i}=w\left(i+\frac{1}{2}\right)(5)
$$

Untuk bin B dengan batas $\operatorname{bin}\left[w(i), w(i+1)\right.$ dimana $=\frac{180}{\theta}$. Vote $\operatorname{bin}[i]$ pada setiap cell dengan persamaan (6) (7).

$$
\begin{gathered}
V_{i}=\mu c_{i+1}-\frac{\theta}{w}(6) \\
i=\left[\frac{\theta}{w}-\frac{1}{2}\right] \bmod B(7)
\end{gathered}
$$

Kemudian selanjutnya lakukan Vote Bin[i] pada setiap cell dengan persamaan (8) (9).

$$
\begin{gathered}
V_{i}+1=\mu \theta-\frac{c_{j}}{w}(8) \\
\text { Vote } \operatorname{bin}[(j+i) \bmod B](9)
\end{gathered}
$$

4. Normalisasi kontras blok dari sel yang tumpang tindih (overlapping)

Setelah nilai dari orientasi bin diperoleh, lakukan proses normalisasi untuk mendapatkan nilai $b$ tiap blok agar nantinya mengurangi terjadinya tumpang tindih (overlaping). Normalisasi setiap blok yang terdiri dari $c \times c$ cell dengan menggunakan persamaan berikut (10).

$$
b=\frac{b}{\sqrt{\|b\|^{2}+\varepsilon}}(10)
$$

Lalu lakukan normalisasi setiap fitur HOG dari setiap blok dengan persamaan (11).

$$
h=\frac{h}{\sqrt{\|h\|^{2}+\varepsilon}}(11)
$$

5. Kumpulkan vektor HOG dari semua blok melalui detection window .

\subsection{Linear Discriminant Analysis}

LDA adalah metode ekstraksi fitur dengan perpaduan dari perhitungan operasi matematika dan statistika yang memberlakukan properti statistik terpisah untuk tiap obyek. Tujuan metode LDA adalah mencari proyeksi linier (yang biasa disebut dengan 'fisherimage') untuk memaksimumkan matriks kovarian antar kelas (between-class covariance matrix) sekaligus meminimumkan matriks kovarian dalam kelas (within-class covariance matrix), agar anggota di dalam kelas lebih terkumpul penyebarannya dan pada akhirnya dapat meningkatkan keberhasilan pengenalan.

Matriks kovarian dalam kelas $\left(S_{W}\right)$ dan matriks kovarian antar kelas $\left(S_{B}\right)$ masing-masing dihitung dengan persamaan (12) (13).

$$
\begin{gathered}
\mathrm{S}_{\mathrm{W}}=\sum_{\mathrm{i}=1}^{\mathrm{c}} \sum_{\mathrm{X}_{\mathrm{k}} \in \mathrm{X}_{1}}\left(\mathrm{x}_{\mathrm{k}}-\mu_{\mathrm{i}}\right)\left(\mathrm{x}_{\mathrm{k}}-\mu_{\mathrm{i}}\right)^{\mathrm{T}}(12) \\
\mathrm{S}_{\mathrm{B}}=\sum_{\mathrm{i}=1}^{\mathrm{c}} \mathrm{N}_{\mathrm{i}}\left(\mu_{\mathrm{i}}-\mu\right)\left(\mu_{\mathrm{i}}-\mu\right)^{\mathrm{T}}(13)
\end{gathered}
$$


Agar matriks kovarian dalam kelas $\left(S_{W}\right)$ dapat diminimalisasi sementara matriks kovarian antar kelas $\left(S_{B}\right)$ dimaksimalkan, maka akan dicari vektor eigen $(v)$ dengan persamaan (14).

$$
\frac{\operatorname{det}\left(V S_{B} V^{T}\right)}{\operatorname{det}\left(V S_{W} V^{T}\right)}(14)
$$

Sehingga menghasilkan solusi (15).

$$
S_{B} V=\lambda S_{B} V(15)
$$

Kemudian dicari nilai eigen $(\lambda)$ dan vektor eigen $(V)$ dari matriks kovarian dengan persamaan (16).

$$
\operatorname{cov}=S_{B} S_{W}^{-1}(16)
$$

\section{4 k-Nearest Neighbor $(k-N N)$}

Algoritma k-NN merupakan metode klasifikasi yang mengelompokan data baru berdasarkan jarak data baru itu kebeberapa data (neighbors) terdekat [12][13]. Teknik K-NN dilakukan dengan melakukan langkah-langkah [13], mulai input data training, label data traning, $\mathrm{k}$, dan data testing.

1. Untuk semua data testing, hitung jaraknya ke setiap data training. Akumulasi bobot nilai untuk orientasi gradient di dalam ruang cell.

2. Tentukan k data training yang jaraknya paling dekat dengan data.

3. Testing.

4. Periksa label dari $\mathrm{k}$ data.

5. Masukan data testing ke kelas dengan frekuensi paling banyak.

6. Berhenti.

\subsection{Distance}

Metode perhitungan distance yang digunakan pada penelitian untuk proses klasifikasi kNN ada 3 yaitu, Euclidean Distance, Manhattan Distance, dan Chebyshev Distance.

1. Euclidean Distance: digunakan untuk mengukur antara dua titik dalam satu dimensi [14]. Persamaan untuk menghitung Euclidean Distance dapat dilihat pada persamaan (17).

$$
d_{\text {euclidean }}=\sqrt{\left(X_{1}-X_{2}\right)^{2}+\left(Y_{1}+Y_{2}\right)^{2}}(17)
$$

2. Manhattan Distance: digunakan untuk menghitung jarak dengan tujuan untuk mendapatkan jarak dari satu titik data ke titik data yang lain. Manhattan mencerminkan jarak antara titik di jalan perkotaan dalam satu blok [14]. Persamaan untuk menghitung Manhattan Distance dapat dilihat pada persamaan (18).

$$
d_{\text {manhattan }}=\left|X_{1}-X_{2}\right|+\left|Y_{1}-Y_{2}\right|
$$

3. Chebyshev Distance: merupakan perhitungan jarak yang menghitung besarnya hasil absolut dari perbedaan antara sepasang objek [14]. Persamaan untuk menghitung Chebyshev Distance dapat dilihat pada persamaan (19).

\subsection{Confusion Matrix}

$$
d_{\text {chebychev }}=\max \left(\left|X_{1}-X_{2}\right|,\left|Y_{1}-Y_{2}\right|(19)\right.
$$

Proses pengujian menggunakan metode presicion, recall, dan accuracy. Precision dan recall digunakan untuk mengukur kinerja sistem. Precision merupakan kecocokan antara 
bagian data yang diambil dengan informasi yang dibutuhkan. Recall merupakan tingkat keberhasilan sistem dalam menemukan kembali sebuah informasi. Sedangkan accuracy merupakan tingkat kedekatan antara nilai yang didapat terhadap nilai sebenarnya.

Adapun cara menghitung confusion matrix menggunakan persamaan (20) (21) (22).

$$
\begin{array}{r}
\text { Precision }=\frac{T P}{T P+F P}(20) \\
\text { Recall }=\frac{T P}{T P+F N}(21) \\
\text { Accuracy }=\frac{T P+T N}{T P+T N+F P+F N}
\end{array}
$$

\section{METODE PENELITIAN}

\subsection{Identifikasi Masalah}

Menemukan permasalahan sesuai bidang ilmu, dalam hal ini adalah belum adanya pengenalan pola ASL menggunakan k-NN serta metode ekstraksi HOG dan LDA

\subsection{Studi Literatur}

Tahapan ini merupakan pencarian beberapa jurnal yang terkait mengenai klasifikasi ejaan jari menggunakan bermacam metode yang digunakan, jurnal yang terkait mengenai metode ektraksi fitur HOG dan LDA serta metode klasifikasi k-NN)

\subsection{Pengumpulan Data}

Pengumpulan data menggunakan dataset ASL yang berjumlah 240 citra RGB, masingmasing berukuran 320x240 piksel. Dataset ini terdiri dari 24 kelas dari alfabet ASL (A-Y) kecuali $\mathrm{J}$ dan $\mathrm{Z}$ karena bersifat dinamis dan setiap kelas terdiri dari 10 citra.

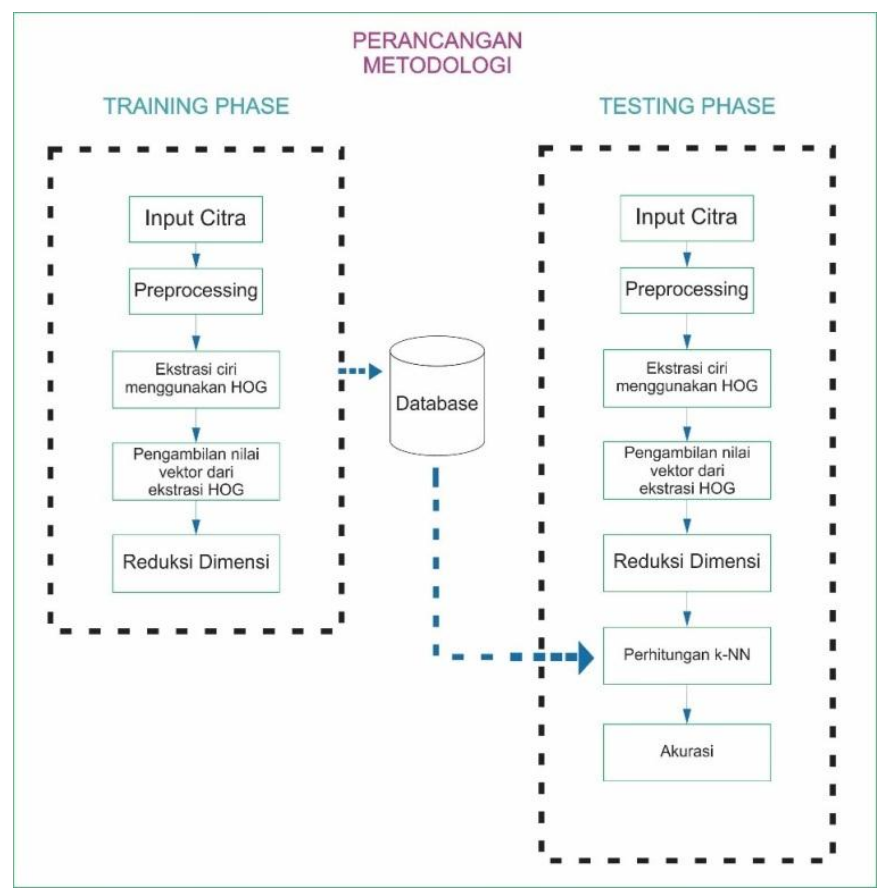

Gambar 1. Metodologi Penelitian 


\subsection{Perancangan}

Melakukan perancangan skema dalam menggunakan k-NN mula-mula melakukan tahap pra-proses dimana proses citra yang diambil akan melakukan tahap cropping pada bagian citra dan ekstraksi fitur menggunakan HOG dan LDA serta melanjutkan proses klasifikasi menggunakan k-NN. Bagan perancangan keseluruhan dapat dilihat pada Gambar 2.

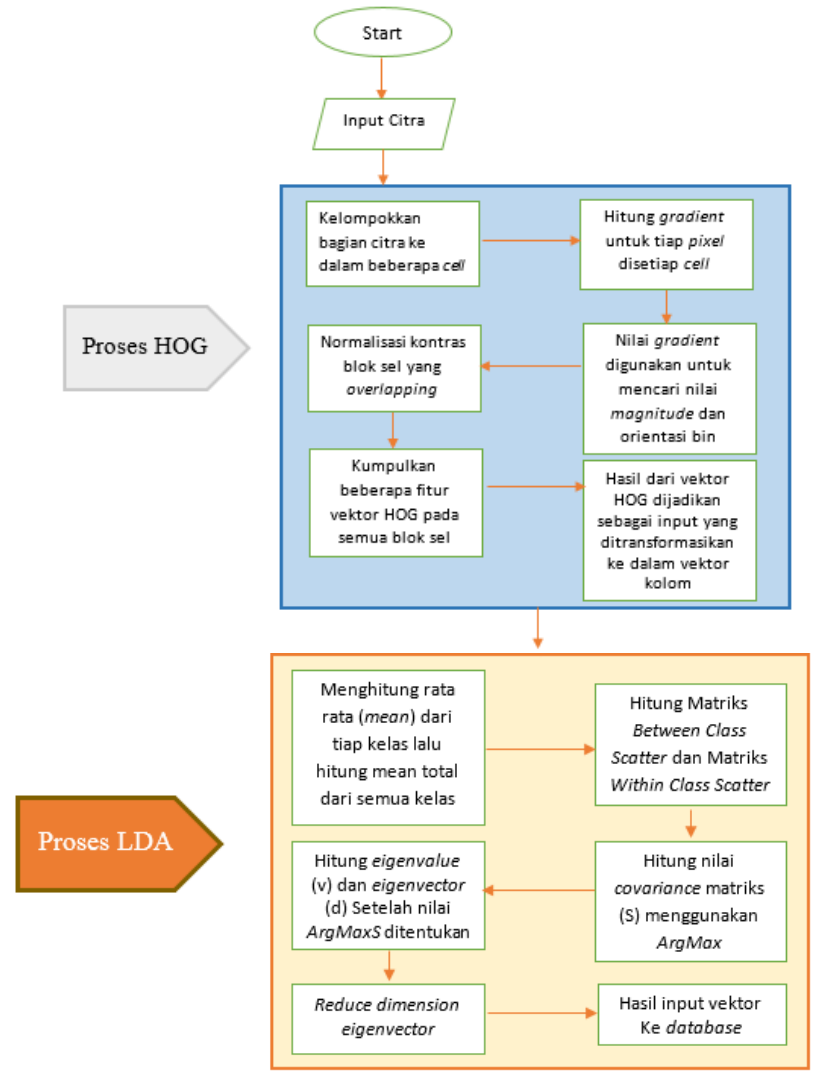

Gambar 2. Perancangan

\subsection{Implementasi}

Setelah pada tahapan ini dilakukan implementasi rancangan yang sudah dibuat pada tahap perancangan ke dalam bentuk bahasa pemrograman, lalu dilakukan pengujian pada tahap selanjutnya yaitu tahap evaluasi.

\section{HASIL DAN PEMBAHASAN}

\subsection{Implementasi}

Pada tahap ini dilakukan implementasi proses pada penelitian untuk memperoleh hasil yang dibutuhkan didalam penelitian, seperti ekstraksi fitur HOG dan LDA serta metode k-NN sebagai proses klasifikasi.

\subsubsection{Implementasi Ekstraksi HOG}

Pada tahap implementasi ekstraksi fitur HOG dilakukan proses grayscale, yaitu citra RGB diubah menjadi citra grayscale. Proses HOG ini dilakukan terhadap citra training dan testing yang telah melalui tahap preprocessing sebelumnya. Sehingga diperoleh citra berukuran 91 x 91 piksel dengan nilai Gx dan Gy untuk mendapatkan nilai magnitude dan orientasi bining. 
Adapun jumlah cell adalah [8 8] dan jumlah block adalah [2 2], sehingga jumlah cell dan block perlu diubah karena ukuran citra adalah 91 x 91 piksel. Maka jumlah cell yang didapat adalah [11 11] dan jumlah block yang didapat adalah [10 10]. Dengan ukuran cell [2 2] = 4 cell yang berisi 9 bin dengan ukuran block [10 10] = 100 block, sehingga 100 block x 9 bin x 4 cell diperoleh fitur HOG yaitu 3600. Hasil dari HOG berupa nilai vektor dari matrik berukuran 1176 x 3600 untuk data training dan nilai vektor dari matrik berukuran dari 504 x 3600 untuk data testing, yang kemudian masing-masing digunakan sebagai input didalam proses tahapan ekstraksi fitur LDA.

\subsubsection{Implementasi Ekstraksi LDA}

Pada tahap implementasi ekstraksi fitur LDA dilakukan proses reduce dimension dari feature vektor yang diperoleh dari proses HOG. Feature HOG di reduce menjadi 2400 sehingga diperoleh matrik berukuran 1176 × 2400 untuk data training dan matrik berukuran 504 x 2400 untuk data testing yang kemudian selanjutnya digunakan sebagai input dalam proses k-NN. Tahapan ini bertujuan agar proses komputasi yang dilakukan dalam pengenalan objek pada metode k-NN selanjutnya menjadi tidak terlalu berat karena feature vektor yang telah di reduce.

\subsubsection{Implementasi metode $k-N N$}

Pada tahap implementasi metode k-NN akan dilakukan proses pengujian terhadap data training dan data testing menggunakan nilai vektor dari matrik yang telah di reduce dari proses HOG dan LDA. Hasil Pengujian yang diperoleh dilakukan sebanyak 15 kali dengan menggunakan euclidean, manhattan, dan chebyshev distance, serta menggunakan $\mathrm{k}=3, \mathrm{k}=5, \mathrm{k}$ $=7, \mathrm{k}=9$, dan $\mathrm{k}=11$ untuk masing-masing distance. .

\subsection{Pengujian}

Hasil pengujian berupa nilai precision, recall, dan acuracy berdasarkan tingkat kesesuaian nilai antara predicted label dan data testing yang diperoleh dari metode k-NN.

\subsubsection{Analisis Pengujian Euclidean}

Hasil pengujian menggunakan euclidean distance dapat dilihat pada Gambar 3. Gambar 3 menampilkan hasil precision, recall, dan accuracy menggunakan euclidean distance untuk nilai $\mathrm{k}=3,5,7,9$, dan 11 . Hasil accuracy tertinggi berada pada nilai $\mathrm{k}=3, \mathrm{k}=5$ dan $\mathrm{k}=11$

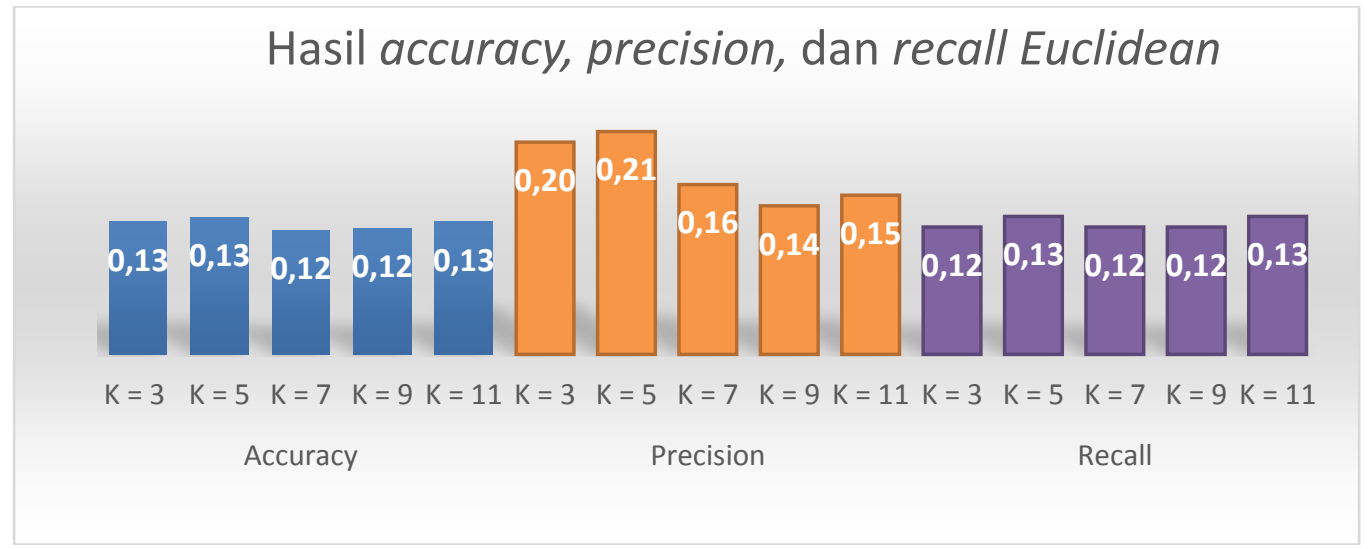

Gambar 3. Analisis Pengujian Euclidean 


\subsubsection{Analisis Pengujian Manhattan}

Hasil pengujian menggunakan manhattan distance dapat dilihat pada Gambar 4. Gambar 4 menampilkan hasil precision, recall, dan accuracy manhattan untuk nilai $\mathrm{k}=3,5,7$, 9, dan 11. Hasil accuracy tertinggi berada pada nilai $\mathrm{k}=3$.

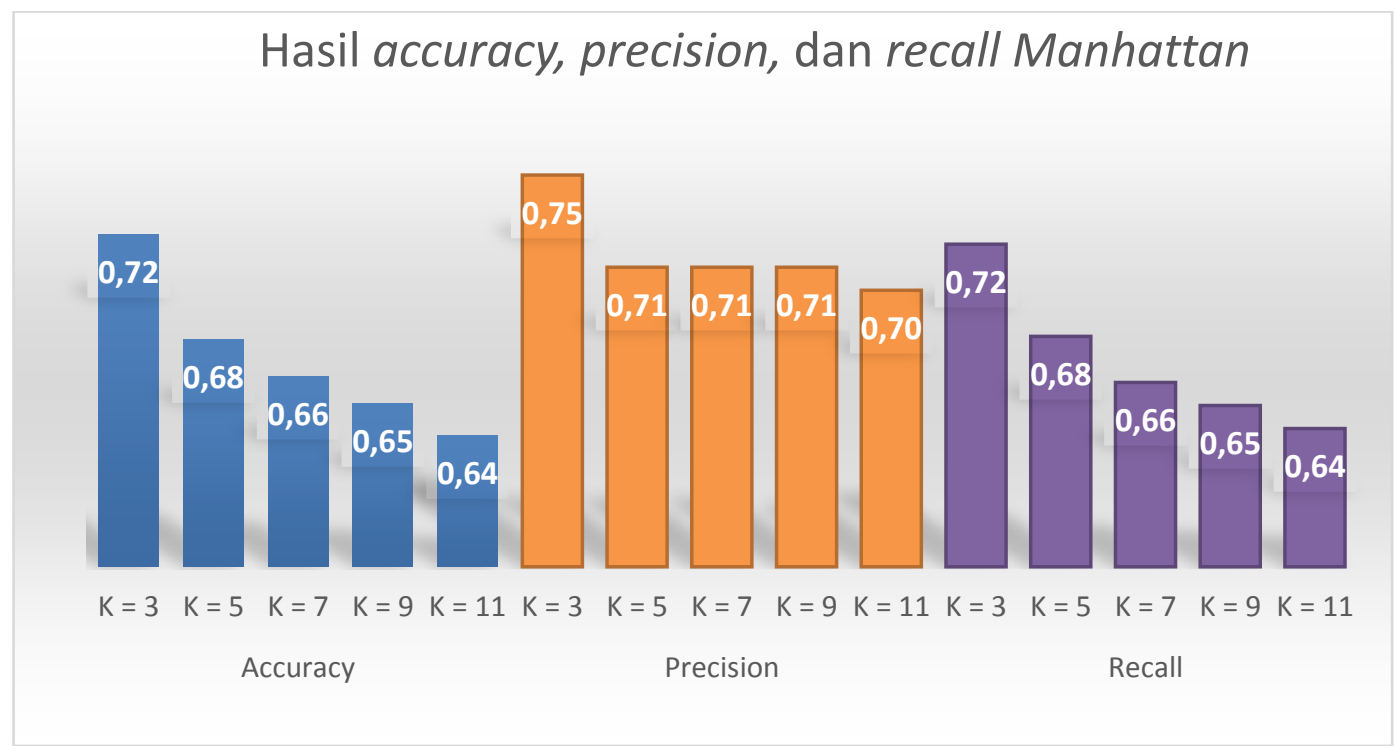

\section{Gambar 4. Analisis Pengujian Manhattan}

\subsubsection{Analisis Pengujian Chebyshev}

Hasil pengujian menggunakan chebyshev distance dapat dilihat pada Gambar 5. Gambar 5 menampilkan hasil precision, recall, dan accuracy chebyshev untuk nilai $\mathrm{k}=3,5,7,9$, dan 11. hasil accuracy tertinggi berada pada nilai $\mathrm{k}=3, \mathrm{k}=9$, dan $\mathrm{k}=11$.

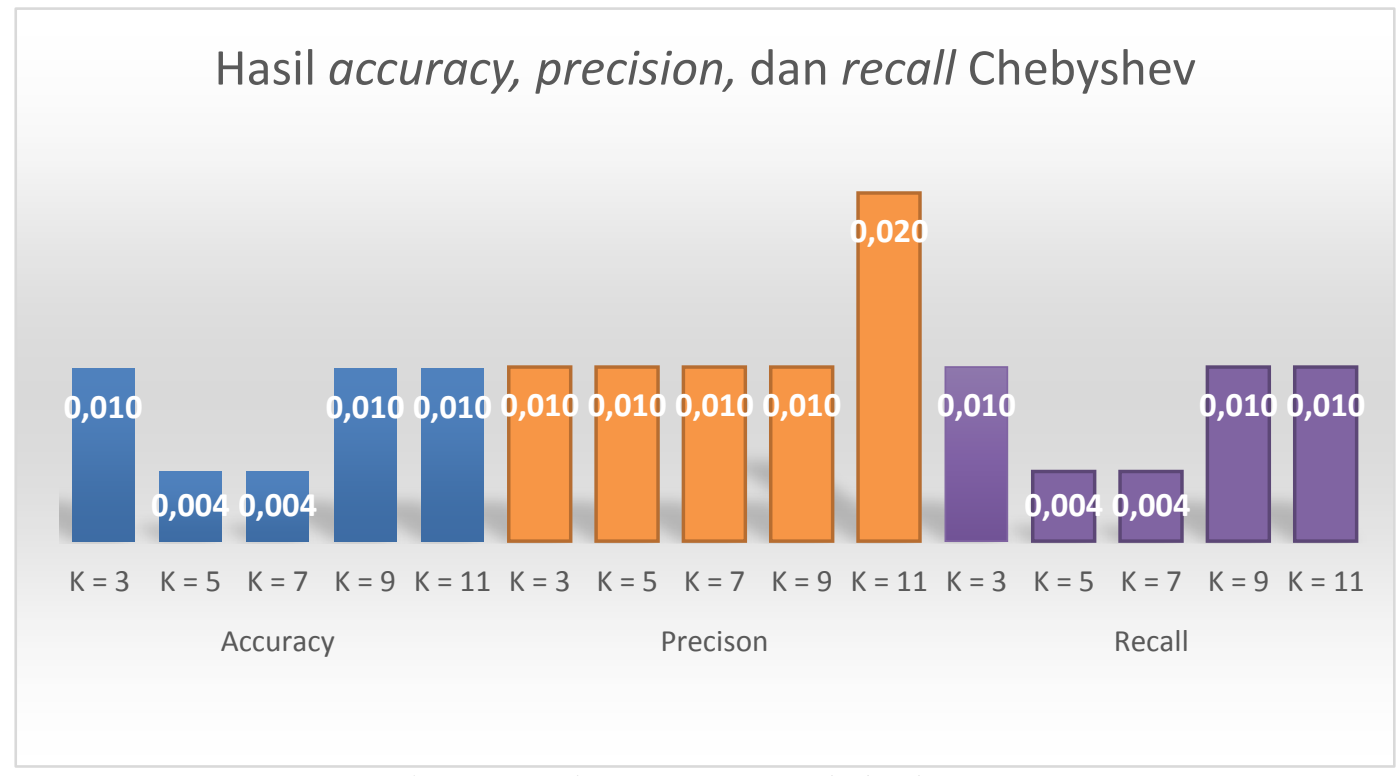

Gambar 5. Analisis Pengujian chebyshev 
Jatisi

ISSN 2407-4322

Vol. 7, No. 2, Agustus 2020, Hal. 214-225 'E-ISSN 2503-2933

222

Hasil pengujian berupa precision, recall dan accuracy per huruf dapat dilihat pada

Tabel 1, Tabel 2 dan Tabel 3.

Tabel 1. Perbandingan Precision untuk Masing-masing Alfabet

\begin{tabular}{|c|c|c|c|c|c|c|c|c|c|c|c|c|c|c|c|}
\hline & \multicolumn{15}{|c|}{ Precision } \\
\hline & \multicolumn{5}{|c|}{ Euclidean } & \multicolumn{5}{|c|}{ Manhattan } & \multicolumn{5}{|c|}{ Chebyshev } \\
\hline & 3 & 5 & 7 & 9 & 11 & 3 & 5 & 7 & 9 & 11 & 3 & 5 & 7 & 9 & 11 \\
\hline $\mathrm{A}$ & 0,22 & 0,17 & 0 & 0 & 0,09 & 0,76 & 0,65 & 0,64 & 0,62 & 0,58 & 0 & 0 & 0 & 0 & 0 \\
\hline B & 0 & 0 & 0 & 0 & 0 & 0,5 & 0,43 & 0,4 & 0,38 & 0,36 & 0 & 0 & 0 & 0 & 0 \\
\hline $\mathrm{C}$ & 0,1 & 0,09 & 0,07 & 0,10 & 0,12 & 0,64 & 0,63 & 0,59 & 0,62 & 0,68 & 0 & 0 & 0 & 0 & 0,25 \\
\hline D & 0,09 & 0,11 & 0,10 & 0,12 & 0,12 & 0,74 & 0,67 & 0,71 & 0,75 & 0,7 & 0 & 0 & 0 & 0 & 0 \\
\hline $\mathrm{E}$ & 0,07 & 0,09 & 0,10 & 0,1 & 0,08 & 0,84 & 0,82 & 0,82 & 0,77 & 0,77 & 0 & 0 & 0 & 0 & 0 \\
\hline $\mathrm{F}$ & 0,13 & 0,11 & 0,17 & 0,17 & 0,25 & 0,71 & 0,68 & 0,77 & 0,8 & 0,71 & 0 & 0 & 0 & 0 & 0 \\
\hline G & 0,6 & 1 & 1 & 0,75 & 0,67 & 0,85 & 0,70 & 0,77 & 0,77 & 0,77 & 0,01 & 0,004 & 0,004 & 0,004 & 0,004 \\
\hline $\mathrm{H}$ & 0,6 & 0,6 & 0,86 & 0,86 & 0,86 & 0,83 & 0,81 & 0,86 & 0,86 & 0,86 & 0 & 0 & 0 & 0 & 0 \\
\hline I & 0,25 & 0,43 & 0,17 & 0,29 & 0,4 & 0,68 & 0,76 & 0,71 & 0,79 & 0,83 & 0 & 0 & 0 & 0 & 0 \\
\hline $\mathrm{K}$ & 0,2 & 0,24 & 0,24 & 0,19 & 0,22 & 0,43 & 0,5 & 0,54 & 0,47 & 0,47 & 0 & 0 & 0 & 0 & 0 \\
\hline $\mathrm{L}$ & 0,05 & 0,11 & 0 & 0,11 & 0,07 & 0,89 & 0,94 & 0,93 & 0,92 & 0,85 & 0,17 & 0,2 & 0,14 & 0,12 & 0,11 \\
\hline $\bar{M}$ & 0,14 & 0,11 & 0,19 & 0,09 & 0,11 & 0,56 & 0,5 & 0,55 & 0,54 & 0,55 & 0,06 & 0 & 0 & 0,04 & 0,08 \\
\hline $\mathrm{N}$ & 0,16 & 0,18 & 0,10 & 0,08 & 0,09 & 0,46 & 0,45 & 0,62 & 1 & 0,67 & 0 & 0 & 0 & 0,12 & 0 \\
\hline $\mathrm{O}$ & 0,08 & 0,08 & 0,09 & 0,08 & 0,08 & 0,81 & 0,75 & 0,71 & 0,69 & 0,68 & 0 & 0 & 0 & 0 & 0 \\
\hline$P$ & 1 & 1 & 0,5 & 0 & 0 & 1 & 1 & 1 & 1 & 1 & 0 & 0 & 0 & 0 & 0 \\
\hline Q & 0 & 0 & 0 & 0 & 0,04 & 1 & 1 & 1 & 0,93 & 0,94 & 0 & 0 & 0 & 0 & 0 \\
\hline$\overline{\mathrm{R}}$ & 0 & 0 & 0 & 0 & 0 & 0,6 & 0,56 & 0,33 & 0,4 & 0,43 & 0 & 0 & 0 & 0 & 0 \\
\hline $\mathrm{S}$ & 0,5 & 0 & 0 & 0 & 0 & 0,81 & 0,71 & 0,90 & 0,67 & 0,73 & 0 & 0 & 0 & 0 & 0 \\
\hline $\mathrm{T}$ & 0 & 0,33 & 0 & 0 & 0 & 0,94 & 0,94 & 0,94 & 0,94 & 0,94 & 0 & 0 & 0 & 0 & 0 \\
\hline $\mathrm{U}$ & 0 & 0 & 0 & 0 & 0 & 0,68 & 0,61 & 0,58 & 0,5 & 0,52 & 0 & 0 & 0 & 0 & 0 \\
\hline $\mathrm{V}$ & 0 & 0 & 0 & 0 & 0 & 0,63 & 0,5 & 0,38 & 0,4 & 0,4 & 0 & 0 & 0 & 0 & 0 \\
\hline W & 0 & 0 & 0 & 0 & 0 & 0,6 & 0,45 & 0,4 & 0,4 & 0,4 & 0 & 0 & 0 & 0 & 0 \\
\hline$X$ & 0 & 0 & 0,056 & 0,045 & 0 & 1 & 1 & 0,86 & 0,86 & 1 & 0 & 0 & 0 & 0 & 0 \\
\hline $\mathrm{Y}$ & 0,5 & 0,308 & 0,222 & 0,4 & 0,36 & 0,93 & 1 & 1 & 0,89 & 0,94 & 0 & 0 & 0 & 0 & 0 \\
\hline
\end{tabular}

Tabel 2. Perbandingan Recall untuk Masing-masing Alfabet

\section{Recall}

\section{Euclidean}

Manhattan

Chebyshev

\begin{tabular}{|c|c|c|c|c|c|c|c|c|c|c|c|c|c|c|c|}
\hline & 3 & 5 & 7 & 9 & 11 & 3 & 5 & 7 & 9 & 11 & 3 & 5 & 7 & 9 & 11 \\
\hline A & 0,19 & 0,19 & 0 & 0 & 0,05 & 0,90 & 0,81 & 0,95 & 0,86 & 0,71 & 0 & 0 & 0 & 0 & 0 \\
\hline B & 0 & 0 & 0 & 0 & 0 & 0,95 & 1 & 0,95 & 0,95 & 0,95 & 0 & 0 & 0 & 0 & 0 \\
\hline C & 0,38 & 0,28 & 0,24 & 0,28 & 0,28 & 0,95 & 0,90 & 0,76 & 0,71 & 0,71 & 0 & 0 & 0 & 0 & 0,05 \\
\hline D & 0,24 & 0,24 & 0,24 & 0,28 & 0,28 & 0,80 & 0,76 & 0,71 & 0,57 & 0,33 & 0 & 0 & 0 & 0 & 0 \\
\hline E & 0,28 & 0,28 & 0,24 & 0,24 & 0,19 & 1 & 0,86 & 0,86 & 0,81 & 0,81 & 0 & 0 & 0 & 0 & 0 \\
\hline F & 0,14 & 0,14 & 0,19 & 0,14 & 0,24 & 0,95 & 1 & 0,95 & 0,95 & 0,95 & 0 & 0 & 0 & 0 & 0 \\
\hline G & 0,14 & 0,14 & 0,14 & 0,14 & 0,09 & 0,81 & 0,76 & 0,81 & 0,81 & 0,81 & 0,09 & 0,05 & 0,05 & 0,05 & 0,05 \\
\hline H & 0,14 & 0,14 & 0,28 & 0,28 & 0,28 & 0,95 & 0,81 & 0,86 & 0,86 & 0,86 & 0 & 0 & 0 & 0 & 0 \\
\hline I & 0,09 & 0,14 & 0,05 & 0,09 & 0,09 & 0,71 & 0,76 & 0,71 & 0,71 & 0,71 & 0 & 0 & 0 & 0 & 0 \\
\hline K & 0,19 & 0,28 & 0,28 & 0,24 & 0,28 & 0,48 & 0,52 & 0,71 & 0,67 & 0,71 & 0 & 0 & 0 & 0 & 0 \\
\hline L & 0,05 & 0,09 & 0 & 0,09 & 0,05 & 0,81 & 0,81 & 0,67 & 0,57 & 0,52 & 0,09 & 0,05 & 0,05 & 0,05 & 0,05 \\
\hline
\end{tabular}




\begin{tabular}{|c|c|c|c|c|c|c|c|c|c|c|c|c|c|c|c|}
\hline $\mathrm{M}$ & 0,09 & 0,05 & 0,19 & 0,09 & 0,14 & 0,43 & 0,38 & 0,52 & 0,57 & 0,52 & 0,05 & 0 & 0 & 0,05 & 0,09 \\
\hline $\mathrm{N}$ & 0,28 & 0,24 & 0,19 & 0,19 & 0,24 & 0,28 & 0,24 & 0,24 & 0,24 & 0,28 & 0 & 0 & 0 & 0,09 & 0 \\
\hline $\mathrm{O}$ & 0,28 & 0,28 & 0,38 & 0,33 & 0,33 & 0,81 & 0,71 & 0,81 & 0,86 & 0,81 & 0 & 0 & 0 & 0 & 0 \\
\hline $\mathrm{P}$ & 0,05 & 0,14 & 0,05 & 0 & 0 & 0,90 & 0,81 & 0,67 & 0,67 & 0,57 & 0 & 0 & 0 & 0 & 0 \\
\hline $\mathrm{Q}$ & 0 & 0 & 0 & 0 & 0,05 & 0,71 & 0,71 & 0,67 & 0,67 & 0,76 & 0 & 0 & 0 & 0 & 0 \\
\hline $\mathrm{R}$ & 0 & 0 & 0 & 0 & 0 & 0,57 & 0,48 & 0,28 & 0,19 & 0,28 & 0 & 0 & 0 & 0 & 0 \\
\hline $\mathrm{S}$ & 0,05 & 0 & 0 & 0 & 0 & 0,62 & 0,48 & 0,38 & 0,38 & 0,38 & 0 & 0 & 0 & 0 & 0 \\
\hline $\mathrm{T}$ & 0 & 0,05 & 0 & 0 & 0 & 0,81 & 0,76 & 0,76 & 0,76 & 0,71 & 0 & 0 & 0 & 0 & 0 \\
\hline $\mathrm{U}$ & 0 & 0 & 0 & 0 & 0 & 0,76 & 0,76 & 0,71 & 0,71 & 0,71 & 0 & 0 & 0 & 0 & 0 \\
\hline $\mathrm{V}$ & 0 & 0 & 0 & 0 & 0 & 0,48 & 0,24 & 0,24 & 0,28 & 0,38 & 0 & 0 & 0 & 0 & 0 \\
\hline $\mathrm{W}$ & 0 & 0 & 0 & 0 & 0 & 0,71 & 0,67 & 0,67 & 0,76 & 0,76 & 0 & 0 & 0 & 0 & 0 \\
\hline $\mathrm{X}$ & 0 & 0 & 0,05 & 0,05 & 0 & 0,28 & 0,33 & 0,28 & 0,28 & 0,24 & 0 & 0 & 0 & 0 & 0 \\
\hline $\mathrm{Y}$ & 0,38 & 0,38 & 0,28 & 0,38 & 0,38 & 0,67 & 0,71 & 0,71 & 0,76 & 0,76 & 0 & 0 & 0 & 0 & 0 \\
\hline
\end{tabular}

Tabel 3. Perbandingan Accuracy untuk Masing-masing Alfabet

\begin{tabular}{|c|c|c|c|c|c|c|c|c|c|c|c|c|c|c|c|}
\hline & \multicolumn{15}{|c|}{ Accuracy } \\
\hline & \multicolumn{5}{|c|}{ Euclidean } & \multicolumn{5}{|c|}{ Manhattan } & \multicolumn{5}{|c|}{ Chebyshev } \\
\hline & 3 & 5 & 7 & 9 & 11 & 3 & 5 & 7 & 9 & 11 & 3 & 5 & 7 & 9 & 11 \\
\hline $\mathrm{A}$ & 0,94 & 0,93 & 0,94 & 0,95 & 0,94 & 0,98 & 0,97 & 0,98 & 0,97 & 0,97 & 0,90 & 0,90 & 0,91 & 0,90 & 0,90 \\
\hline B & 0,94 & 0,92 & 0,93 & 0,93 & 0,93 & 0,96 & 0,94 & 0,94 & 0,93 & 0,93 & 0,95 & 0,95 & 0,95 & 0,95 & 0,95 \\
\hline $\mathrm{C}$ & 0,83 & 0,85 & 0,84 & 0,86 & 0,88 & 0,98 & 0,97 & 0,97 & 0,97 & 0,97 & 0,95 & 0,95 & 0,95 & 0,95 & 0,95 \\
\hline $\mathrm{D}$ & 0,87 & 0,89 & 0,88 & 0,88 & 0,88 & 0,98 & 0,97 & 0,98 & 0,97 & 0,97 & 0,93 & 0,93 & 0,93 & 0,94 & 0,94 \\
\hline $\mathrm{E}$ & 0,81 & 0,85 & 0,88 & 0,88 & 0,88 & 0,99 & 0,97 & 0,99 & 0,98 & 0,98 & 0,93 & 0,95 & 0,94 & 0,94 & 0,95 \\
\hline $\mathrm{F}$ & 0,92 & 0,92 & 0,93 & 0,94 & 0,94 & 0,98 & 0,98 & 0,98 & 0,99 & 0,98 & 0,94 & 0,94 & 0,94 & 0,95 & 0,95 \\
\hline $\mathrm{G}$ & 0,96 & 0,96 & 0,96 & 0,96 & 0,96 & 0,99 & 0,98 & 0,98 & 0,98 & 0,98 & 0,51 & 0,50 & 0,50 & 0,51 & 0,50 \\
\hline $\mathrm{H}$ & 0,96 & 0,96 & 0,97 & 0,97 & 0,97 & 0,99 & 0,98 & 0,99 & 0,99 & 0,99 & 0,78 & 0,80 & 0,80 & 0,80 & 0,79 \\
\hline I & 0,95 & 0,96 & 0,95 & 0,95 & 0,96 & 0,97 & 0,98 & 0,98 & 0,98 & 0,98 & 0,95 & 0,94 &, 95 & 0,95 & 0,95 \\
\hline $\mathrm{K}$ & 0,93 & 0,93 & 0,93 & 0,93 & 0,93 & 0,95 & 0,96 & 0,96 & 0,95 & 0,95 & 0,93 & 0,94 & 0,93 & 0,93 & 0,94 \\
\hline $\mathrm{L}$ & 0,92 & 0,93 & 0,92 & 0,93 & 0,93 & 0,99 & 0,99 & 0,98 & 0,98 & 0,98 & 0,94 & 0,95 & 0,95 & 0,95 & 0,94 \\
\hline $\mathrm{M}$ & 0,94 & 0,94 & 0,93 & 0,92 & 0,92 & 0,96 & 0,96 & 0,96 & 0,96 & 0,96 & 0,93 & 0,92 & 0,91 & 0,92 & 0,91 \\
\hline $\mathrm{N}$ & 0,91 & 0,92 & 0,90 & 0,88 & 0,87 & 0,96 & 0,97 & 0,96 & 0,97 & 0,96 & 0,93 & 0,93 & 0,93 & 0,93 & 0,94 \\
\hline $\mathrm{O}$ & 0,83 & 0,83 & 0,82 & 0,81 & 0,80 & 0,98 & 0,98 & 0,98 & 0,98 & 0,98 & 0,96 & 0,96 & 0,96 & 0,96 & 0,96 \\
\hline $\mathrm{P}$ & 0,96 & 0,96 & 0,96 & 0,96 & 0,96 & 0,99 & 0,99 & 0,99 & 0,99 & 0,98 & 0,92 & 0,91 & 0,91 & 0,91 & 0,91 \\
\hline $\mathrm{Q}$ & 0,93 & 0,92 & 0,91 & 0,91 & 0,92 & 0,99 & 0,99 & 0,99 & 0,98 & 0,99 & 0,96 & 0,95 & 0,95 & 0,95 & 0,95 \\
\hline $\mathrm{R}$ & 0,96 & 0,95 & 0,95 & 0,95 & 0,95 & 0,97 & 0,96 & 0,95 & 0,95 & 0,95 & 0,95 & 0,95 & 0,95 & 0,95 & 0,95 \\
\hline $\mathrm{S}$ & 0,96 & 0,95 & 0,95 & 0,95 & & 0,98 & 0,97 & 0,97 & 0,97 & 0,97 & 0,96 & 95 & 5 & 0,95 & 0,95 \\
\hline $\mathrm{T}$ & 0,95 & 0,96 & 0,96 & 0,96 & 0,96 & 0,99 & 0,99 & 0,99 & 0,99 & 0,99 & 0,95 & 0,94 & 0,94 & 0,95 & 0,95 \\
\hline $\mathrm{U}$ & 0,96 & 0,96 & 0,96 & 0,96 & 0,96 & 0,97 & 0,97 & 0,97 & 0,96 & 0,96 & 0,95 & 0,95 & 0,95 & 0,94 & 0,95 \\
\hline $\mathrm{V}$ & 0,95 & 0,94 & 0,95 & 0,94 & 0,94 & 0,97 & 0,96 & 0,95 & 0,95 & 0,95 & 0,95 & 0,94 & 0,94 & 0,95 & 0,95 \\
\hline $\mathrm{W}$ & 0,96 & 0,96 & 0,96 & 0,95 & 0,95 & 0,97 & 0,95 & 0,95 & 0,94 & 0,94 & 0,95 & 0,95 & 0,95 & 0,95 & 0,95 \\
\hline$X$ & 0,94 & 0,91 & 0,93 & 0,92 & 0,92 & 0,97 & 0,97 & 0,97 & 0,97 & 0,97 & 0,95 & 0,95 & 0,95 & 0,96 & 0,95 \\
\hline$Y$ & 0,96 & 0,94 & 0,93 & 0,95 & 0,95 & 0,98 & 0,99 & 0,99 & 0,99 & 0,99 & 0,94 & 0,94 & 0,94 & 0,94 & 0,94 \\
\hline
\end{tabular}




\section{KESIMPULAN}

Berdasarkan hasil pengujian dapat disimpulkan bahwa:

1. Hasil penerapan metode ekstraksi HOG dan LDA beserta metode klasifikasi k-NN untuk pengenalan american sign language (ASL) memperoleh akurasi tertinggi saat menggunakan manhattan distance untuk $\mathrm{K}=3$, yaitu sebanyak $72 \%$.

2. Jenis distance yang terbaik setelah manhattan distance yaitu euclidean distance lalu terakhir chebyshev distance.

\section{SARAN}

Berdasarkan kesimpulan tersebut, untuk menghasilkan hasil accuracy yang lebih baik, berikut saran yang nantinya dapat bermanfaat untuk penelitian selanjutnya.

1. Sebaiknya menggunakan algoritma ekstraksi fitur dan algoritma klasifikasi yang lain agar bisa mengetahui accuracy yang mana yang lebih baik.

2. Sebaiknya menggunakan dataset yang berbeda, melakukan pengambilan foto dengan jarak dan posisi objek secara konsisten.

\section{DAFTAR PUSTAKA}

[1] K. Otiniano-Rodriguez, E. Cayllahua-Cahuina, A. A. De Araujo, and G. CamaraChavez, 2015. "Finger Spelling Recognition Using Kernel Descriptors and Depth Images," Brazilian Symp. Comput. Graph. Image Process., Vol. 2015-Octob, pp. 72-79.

[2] R. Ridwang, 2017. "Pengenalan Bahasa Isyarat Indonesia (SIBI) Menggunakan Leap Motion Controller dan Algoritma Data Mining Naïve Bayes," J. Insypro (Information Syst. Process., Vol. 2, No. 2.

[3] D. Aryanie and Y. Heryadi, 2015. "American Sign Language-Based Finger-Spelling Recognition Using k-Nearest Neighbors Classifier,” 2015 3rd Int. Conf. Inf. Commun. Technol. ICoICT 2015, pp. 533-536.

[4] I. Fareza, R. Busdin, M. E. Al Rivan, and H. Irsyad, 2018. "Pengenalan Alfabet Bahasa Isyarat Amerika Menggunakan Edge Oriented Histogram dan Image Matching," J. Tek. Inform. dan Sist. Inf., Vol. 4, No. April, pp. 82-92.

[5] F. Fandiansyah, J. Y. Sari, and I. P. Ningrum, 2017, "Pengenalan Wajah Menggunakan Metode Linear Discriminant Analysis dan k Nearest Neighbor," J. Ultim., Vol. 9, No. 1, pp. $1-9$,

[6] D. M. Viswanathan and S. M. Idicula, 2014. "Recognition of Hand Gestures of English Alphabets Using HOG Method," Proc. - 2014 Int. Conf. Data Sci. Eng. ICDSE 2014, pp. 219-223.

[7] M. E. Al Rivan, H. Irsyad, A. T. Narta, and K. Kevin, 2019, "Pengenalan Alfabet American Sign Language Menggunakan K-Nearest Neighbors dengan Ekstraksi Fitur Histogram of Oriented Gradients, "Vol. 5, pp. 328-339,. 
[8] D. Amputri, S. Nadra, G. Gasim, and M. E. Al Rivan, 2017. "Perbandingan Jarak Potret dan Resolusi Kamera pada Tingkat Akurasi Pengenalan Angka kwh Meter Menggunakan svm," J. Inform. Glob., Vol. 8, No. 1, pp. 7-12.

[9] Elissa Rosen, 2005, "History of ASL."

[10] M. Nachamai, 2013, "Alphabet Recognition of American Sign Language: a Hand Gesture Recognition Approach Using Sift Algorithm,” Int. J. Artif. Intell. Appl., Vol. 4, No. 1, pp. 105-115,

[11] N. Dalal and B. Triggs, 2005, "Histograms of Oriented Gradients for Human Detection," in Proceedings - 2005 IEEE Computer Society Conference on Computer Vision and Pattern Recognition, CVPR, Vol. I, pp. 886-893.

[12] K. Velmurugan and S. S. Baboo, 2011. "Content-Based Image Retrieval Using SURF and Colour Moments," Glob. J. Comput. Sci. Technol., Vol. 11, No. 10, pp. 1-4,

[13] B. Santosa, 2011, "Data Mining: Teknik Pemanfaatan Data untuk Keperluan Bisnis," Graha Ilmu., Jakarta.

[14] Y. Religia, 2016, "Metode Manhattan, Euclidean dan Chebyshev pada Algoritma KMeans untuk Pengelompokan Status Desa," 